\title{
Monitoring of the level of strategic development of machine- building enterprises in order to increase their competitiveness
}

\author{
A.V. Novikova ${ }^{1}$, V.V. Isaychenkova ${ }^{1 \mathrm{a}}$ \\ ${ }^{1}$ Bryansk State Technical University, 241035, 50-letiya blvd, 7, Bryansk, Russia
}

\begin{abstract}
The article examines aspects of monitoring of the level of machine-building enterprises strategic development based on the determination of their rating. Indicators of an assessment of capacity of the enterprise are presented and proved. The matrix of determination of the level of strategic development of machine-building enterprises on the basis of indicators of capacity of the enterprise and the cost of business is offered.
\end{abstract}

\section{Introduction}

The machine-building sector is one of the leading industry branches in Russia that goes right after raw materials extraction. In modern context of Russia's accession to WTO and sanctions imposed by foreign states, as well as effects of crisis on the economy, the potential development of Russia is in many ways determined by this branch.

On average during last 5 years machine building industry generated up to $14 \%$ of Russian GDP. A great share of population is engaged in this sector $-32 \%$ of all industry employees. Thus, it is difficult to overestimate the significance of the machine-building sector: this sector serves as a basis for the implementation of scientific and technological progress, as a centre of development, improvement and application of knowledge, techniques and innovations. The development level of the machine-building sector and the industry on the whole serves as an indicator of the state of research and development in Russia, reflects the value of development in the field of designing modern technologies and equipment.

Under the market economy conditions, the necessity to tackle tasks of developing Russian economy and boosting its competitiveness poses new challenges in industry sectors management that requires developing methodology and tools of strategic management. These conditions are especially important in the context of the machine-building industry, which is a subsector of the overall industry that should guarantee an economic growth amid economic and political instability [1], [2].

Among tasks that require solutions there is a necessity to improve informational support of strategic management that allows bringing to light trends in machine-building development and increasing the quality of decision-making [3].

\section{Results and discussion}

The authors propose using monitoring of economic systems - in our case the machine-building sector - as a tool designed to solve the tasks of informational support of strategic development.

Monitoring implies continuous observing of an enterprise and analysis of its activities. In this relation one faces the necessity to ensure that the information that can reveal trends of the market and determine factors and reserves of the growth is complete, trustworthy and timely.

Monitoring in the machine-building sector solves the following tasks:

- ensuring regular gathering of information on the condition of the sector;

- conducting an analysis of the obtained data based on the information on various aspects of machinebuilding development;

- detecting inefficient enterprises in order to carry out a bankruptcy procedure or ensure their competitiveness;

- defining absolute, relevant and average indices of activities of enterprises in the machine-building complex;

- studying of the industry dynamics, detection of negative and positive trends;

- designing machine-building development forecasts for short-, medium- and long-term prospective;

- defining a range of measures to avert and overcome consequences of the crisis;

\footnotetext{
a Corresponding author: alice.cissy@gmail.com
} 
The competitiveness of enterprises is determined above all by the level of strategic development and efficiency of business processes. Business processes are individual for each enterprise and their assessment should be based on specialized methods, which complicates the generalization of the efficiency level in order to carry out monitoring.

The strategic development level of the enterprise constantly changes being exposed to the influence of factors of external and internal environment, which is why it is necessary to analyze it on the regular basis. In order to create a methodology of assessing the strategic development level of the enterprise for all potential users it is necessary to define indices that will determine the place of the enterprise on the market.

In modern conditions the profit loses its importance as the main index of efficiency of the enterprise activities. The value of business becomes the most important index because it reflects enterprise's capacity in conditions of constantly changing external environment. In this relation, the authors propose carrying out monitoring of the strategic development level of the machine-building enterprise according to two assessment criteria - the value of business and the capacity of the enterprise.

The value of business consists of five elements [4]:

- operating projects value;

- enterprises's capacity value;

- business reputation value;

- intellectual property value;

- personnel's capacity value.

It is worth noting that the most accurate and widely applied approach to assessing the business value is the income approach. However, it is proposed to use the cost method when defining the business value, taking into account effects of business processes.

The enterprise value will be equal to the difference of its assets and obligations. The choice is determined by a relative simplicity of calculations, which makes monitoring of the strategic development level of the enterprise more available, as well as by the fact that all required indices can be found in the balance sheet of the enterprise. This method can be applied by all interested users - heads of enterprises, economists, third-party analysts [5].

The analysis of the last publications devoted to problems of an assessment of capacity of the enterprise allows allocating the most successful approaches offered by various authors, according to which components of the machine-building enterprise capacity are the following:

- personnel capacity, which reflects overall performance of the operating office of the enterprise through the indicators of a personnel component of production;

- production capacity: potential volume of production, potential opportunities of fixed assets, potential opportunities of use of materials etc;

- financial capacity: potential financial performance of production (profitability, liquidity, solvency), potential investment opportunities;
- technological capacity: ensuring quality of goods, innovative projects on improvement of the equipment;

- information capacity, which characterizes sufficiency of data, its relevance and provides all participants of processes of the enterprise with information;

- scientific and technical capacity, which reflects the level of safety of production with necessary innovations.

For the highest possible efficient assessment of the enterprise capacity, the authors suggest forming a system of indices that define each component of the capacity of the enterprise (table 1).

Table 1. Indices of the machine-building enterprise capacity assessment

\begin{tabular}{|c|c|c|}
\hline $\begin{array}{l}\text { Type of } \\
\text { capacity }\end{array}$ & Indices of assessment & $\begin{array}{l}\text { Specific weight } \\
\text { of indices } \\
\text { group }\end{array}$ \\
\hline $\begin{array}{l}\text { Personnel } \\
\text { capacity }\end{array}$ & $\begin{array}{l}\text { Coefficient of turnover of } \\
\text { employment } \\
\text { Coefficient of turnover of } \\
\text { dismissal } \\
\text { Coefficient of employee } \\
\text { turnover } \\
\text { Changes of annual average } \\
\text { performance }\end{array}$ & 0,15 \\
\hline $\begin{array}{l}\text { Production } \\
\text { capacity }\end{array}$ & $\begin{array}{l}\text { Coefficient of renovation } \\
\text { Coefficient of dismissal } \\
\text { Coefficient of additions to } \\
\text { fixed assets } \\
\text { Coefficient of fixed assets } \\
\text { wear } \\
\text { Coefficient of suitability of } \\
\text { fixed assets } \\
\text { Coefficient of renovation } \\
\text { Coefficient of dismissal } \\
\text { Coefficient of additions to } \\
\text { fixed assets } \\
\text { Coefficient of suitability of } \\
\text { fixed assets } \\
\text { Capital productivity ratio } \\
\text { Capital intensity } \\
\text { Profitability of fixed assets } \\
\text { Productivity of materials } \\
\text { Specific consumption } \\
\text { intensity of materials } \\
\text { Specific weight of material } \\
\text { expenditures in the cost of } \\
\text { production }\end{array}$ & 0,4 \\
\hline $\begin{array}{l}\text { Financial } \\
\text { capacity }\end{array}$ & $\begin{array}{l}\text { Coefficient of financial } \\
\text { independence } \\
\text { Coefficient of day-to-day } \\
\text { liquidity } \\
\text { Coefficient of due liquidity } \\
\text { Coefficient of absolute } \\
\text { liquidity } \\
\text { Profitability of assets } \\
\text { Return on equity } \\
\text { Share of borrowed funds in } \\
\text { the aggregate total of } \\
\text { resources } \\
\text { Share of unobligated assets } \\
\text { in a resilient form } \\
\text { Share of accumulated } \\
\text { capital }\end{array}$ & 0,25 \\
\hline
\end{tabular}




\begin{tabular}{|l|l|l|}
\hline $\begin{array}{l}\text { Type of } \\
\text { capacity }\end{array}$ & Indices of assessment & $\begin{array}{l}\text { Specific weight } \\
\text { of indices } \\
\text { group }\end{array}$ \\
\hline $\begin{array}{l}\text { Information } \\
\text { al capacity }\end{array}$ & $\begin{array}{l}\text { Percentage of employees } \\
\text { supplied with information } \\
\text { Share of employees who } \\
\text { have access to information } \\
\text { Share of workplaces that are } \\
\text { equipped with modern PC }\end{array}$ & 0,1 \\
\hline $\begin{array}{l}\text { Scientific } \\
\text { and } \\
\text { technical } \\
\text { capacity }\end{array}$ & $\begin{array}{l}\text { Share of innovational } \\
\text { processes in the system of } \\
\text { general processes } \\
\text { Share of employees that } \\
\text { participate in the } \\
\text { development and } \\
\text { implementation of } \\
\text { innovations }\end{array}$ & 0,05 \\
\hline
\end{tabular}

Specific weight is assigned to each index in order to calculate an integrated capacity index of the enterprise:

$$
\Pi=\sum \mathrm{x}_{\mathrm{i}}{ }^{*} \mathrm{~d}_{\mathrm{i}}
$$

where $x_{i}$ is the measure of the index, $d_{i}$ is a specific weight of the index.

Thus, the authors propose determining the strategic development level, proceeding from the value of business and capacity of the enterprise (figure 1).

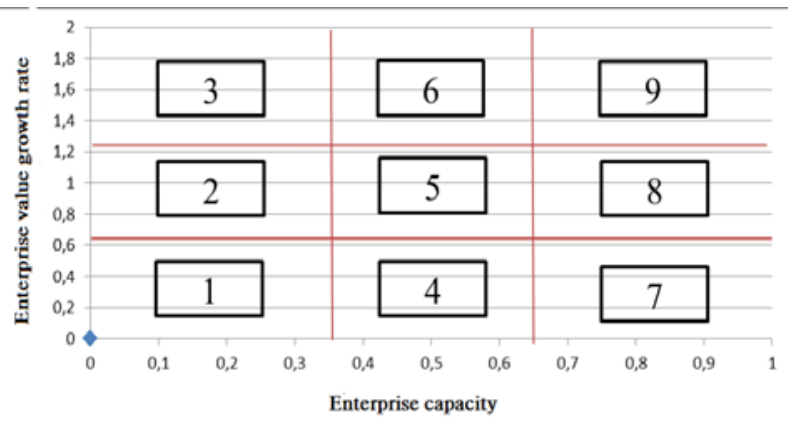

Fig. 1. The matrix determining the level of the enterprise strategic development

If the integrated assessment of the enterprise goes to fields 1,2 and 4 - the enterprise strategic development level is 'weak', field 9 - 'absolute leader', fields 6 and 8 - 'a competitive enterprise', fields 3 and 7 - 'ineffective enterprise', field 5 'an enterprise with a high growth potential'.

For each level of strategic development the corresponding strategy is offered:

1) the weak level of strategic development (position 1) - a strategy of diversification (fig. 1);

2) the weak level of strategic development (positions 2 and 4) - a strategy of elimination of weaknesses of potential and business processes respectively;

3) the inefficient enterprise (positions 3 and 7) - a strategy of a limited growth;

4) the enterprise with a high potential of a growth (position 5) - a growth strategy;

5) a strategically focused enterprise (positions 6 and 8) - a strategy of using opportunities of the internal environment (capacity of the enterprise and business processes respectively);

6) an absolute leader (position 9) - a strategy of enhancing the strengths

This method is allowing defining and comparing the efficiency of various enterprises visually and quickly in view of simplicity of calculation and availability of initial information. On the basis of a technique it is easy to carry out the intercompany comparison (benchmarking) for the purpose of expeditious detection of the provision of the enterprise in the market taking into account its strategic orientation.

On the basis of the calculated indicators it is possible to define reserves of the growth of the strategic development level, defining lag of the specific enterprise from the leading enterprises taking an "absolute leader" position on a matrix of determination of the level of strategic development. It is allowing us to reveal those spheres of activity of the enterprise which need to be restructured for the purpose of increasing competitiveness.

Recently in connection with the increase in the volumes of the informational array, required to provide for the information processes of decision-making in the enterprise, problems of accumulation, integration, systematization, analysis, fast and visual submission of required social and economic information, has become important. Attaching information to a digital board by making a geo-information system (hereinafter referred to as GIS) is a means of solving these tasks.

GIS has the following advantages compared to other information technologies:

- it helps achieving visualization in showing the interrelation of all predicable and graphic data;

- it ensures easy geographic analysis and presentation of the data base in the form of different maps, graphs, diagrams;

- it is a source of structured information for prompt and well-founded managerial decision-making.

The scope of application of GIS in business is wide:

- analysis and monitoring of the current condition of the market and trends of its changes;

- definition of enterprise's strategic development prospects;

- a well-grounded location choice for new enterprises;

- optimizing logistic activities for manufactured production transportation;

- sociological, demographic and economic research conducted in order to reveal trends and changes of the demand.

The state information system that would contain data on the condition of the Russian industry is being presently developed for the Ministry of Industry and Commerce of the Russian Federation. This information is contained in decree of the parliament No. 757 as of July 25,2015 , the planned implementation date is up to January 20, 2016.

The decree of the parliament obliges the Ministry of Industry and Commerce to develop and approve requirements to the state information system of industry. 
In compliance with the decree the state GIS will contain the following elements:

- a complex guaranteeing an access to the information contained in GIS;

- a complex that works out accountability and notification for the users of GIS;

- an analytical complex;

- a complex monitoring and forecasting end markets of industry production and new technologies;

- Russia's industry data storage;

- Other means and tools;

In compliance with FZ-488 on 'Industrial Policy in the Russian Federation' released December 31, 2014, the Ministry of Industry and Commerce explained functions of the geo-information system on the Ministry's webpage. In particular, with its help the control over the state of the industrial production and formation of a sectoral balance system will be conducted. The system is meant to eliminate an artificial surplus of facilities of enterprises that emerge due to lack of tools of expressdiagnostics of economic and manufacturing conditions in specific sectors and regions.

In conditions of modern functioning of the economy, we face the necessity to make a tool ensuring optimal management of the machine-building sector, including its following components: state and private enterprises, a transport lines net, the information system of enterprises interaction.

Geo-information systems allow tackling these tasks. The general development mechanism of GIS implies the following steps:

- Making an integrated information basis;

- Filling in the data base with information on a sector;

- Fulfilling optimization of processes by applying analysis means and lineal programming;

- Analyzing and processing data, bringing them into the line with cartographic information in order to obtain complete accounts on the condition of the industry in question.

The authors propose using GIS-technologies to generalize the submission of data on the strategic development level of the machine-building enterprises in Russia.

The geo-information system developed on the basis of proposed indicators of enterprise's capacity and business value would allow:

- defining promptly the location of enterprises meeting certain requirements;

- finding the most profitable locations for the enterprise, for new subsidiaries and points of sale;

- comparing the level of sales, profits and other indicators for the required period for specific enterprises;

- visually assessing and obtaining a complete statistical summary of the demand and supply dynamics in any area of the machine-building sector, for example, in sales of hopper cars;

- comparing different characteristics of machinebuilding enterprises in different districts, regions and areas using the map and on the basis of other information available on the GIS information;
- identifying the territory with the least/most developed industry in order to find the enterprises, optimally suitable for investment;

- creating a data store, describing various aspects of the functioning of the machine-building sector in Russia;

The geo-information system in machine-building industry has the following tasks:

- to ensure collection, storage, analysis, and integration of information to fulfil informational and analytical functions by heads of enterprises, as well as for the authorities;

- to visually present and analyse the information on the state of enterprises, districts and regions in order to submit it to authorities, research organizations and heads of enterprises;

- to ensure analysis of the data for developing and working out accountings;

- to identify a variety of trends in the development of economy of regions and the country as a whole.

- to create standard and unified templates for the development of similar geo-information systems for specific businesses;

- to ensure information for the prediction of the situation in the machine-building industry.

\section{Conclusion}

Achieving a high level of competitiveness of machinebuilding enterprises and of their strategic development is impossible without analysis of activities of an enterprise. An assessment of each particular business contributes to the achievement of internal goals and objectives, and the integrated characteristics of machine-building industry allows identifying the main trends in the development, and determining the most and least promising enterprises.

Calculation of the provided indicators and carrying out monitoring can also serve the purposes of drawing up ratings of the enterprises of mechanical engineering at various levels - from regional to federal. In that case it is useful to carry out ranging of the enterprises with the indication of the following data:

- the number of the analysed enterprises;

- the list of the enterprises relating to the analyzed territorial units;

- the level of strategic development of the enterprises;

- the level of capacity of the enterprises;

- a rating of the enterprises in the district.

Monitoring of the state of the machine-building sector on the basis of the indices of business value and capacity of enterprises should be carried out according to the results of the assessment. Using the monitoring carried out with the help of GIS technology, one identifies the territory, where, for example, the most effective enterprise is located, which creates the conditions for the development of the industrial cluster. Tracking the state of the industry is necessary for decisions making on the industrial policy of the country in order to assess the impact of the economic and political situation on the industry. 


\section{References}

1. Masayuki Matsui, International Journal of Production Research 51, (2013)

2. V.N. Belkin, N.A Belkina, L.B. Vladykina, Economy of Region 1, (2015)

3. O.I. Botkin, I.V. Grebyonkin, Economy of Region 1, (2014)

4. A.I. Balandin, Economy of Region 3, (2009)

5. Sulaiman Ainin, Noor Akma Mohd Salleh, Shamshul Bahri \& Tengku Mohd Faziharudean, Information Systems Management 32, (2015) 